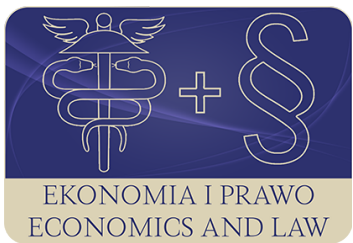

EKONOMIA I PRAWO. ECONOMICS AND LAW

Volume 16, Issue 4, December 2017

p-ISSN 1898-2255, e-ISSN 2392-1625

www.economicsandlaw.pl

ECONOMICS AND LAW

ORIGINAL ARTICLE

received 13.06.2017; revised 01.12.2017; accepted 31.12.2017

Citation: Kuźnar, A., \& Menkes, J. (2017). Will Brexit cause the whole Britain to leave the European Union? Ekonomia i Prawo. Ecomomics and Law, 16(4): 433-448. doi:10.12775/EiP.2017.030.

\title{
Will Brexit cause the whole Britain to leave the European Union?
}

\author{
ANDŻELIKA KUŹNAR \\ corresponding author \\ Warsaw School of Economics, Collegium of World Economy, Institute of International Economics, \\ al. Niepodległości 162, 02-554 Warszawa, Poland \\ $\square$ andzelika.kuznar@sgh.waw.pl
}

JERZY MENKES

Warsaw School of Economics, Collegium of World Economy, Chair of International Law and International Organizations, Poland

曰jerzy.menkes@sgh.waw.pl

\begin{abstract}
Motivation: The results of the referendum on the UK's membership of the EU are far-reaching, but hard to predict. One of the areas related to UK's withdrawal from the EU is whether it will maintain its integrity. The evolving structure of the UK, persistent trends of separatism in the UK, geographical differences in attitudes of UK citizens to Brexit create the background of the study.

Aim: Our goal is to find out whether the effect of Brexit will be leaving the EU by whole Britain and to determine geopolitical and geo-economic consequences of Brexit. The research is an interdisciplinary economic and law study. We use economic (quantitative and qualitative) and legal methods applicable to the research of international institutions using institutional and functional approaches.

Results: Brexit will be a factor of permanent disintegration of UK. Brexit changes the perception and attractiveness of European integration. Brexit will impact the transatlantic order.
\end{abstract}

Keywords: Brexit; EU; European integration; international trade; transatlantic relations JEL: Fl4; F15; F53; K33 


\section{Introduction}

In a referendum on the UK's membership of the European Union held on 23 June 2016 there were $51.9 \%$ votes to leave the EU and $48.1 \%$ to remain in it (turnout was $72.2 \%)^{1}$. Although the referendum was not formally binding, the government decided on Brexit. The decision was based on authorisation by an Act of Parliament ${ }^{2}$. The parliaments of Northern Ireland, Scotland and Wales ${ }^{3}$ were not consulted on the matter.

From the point of view of our research aim it is important that the outcome of the referendum was not evenly distributed across the UK (see: table 1). Wales and England voted to leave EU, while voters in Scotland and Northern Ireland would prefer to stay in EU. Every one local authority area in Scotland voted for 'Remain', while every English region (except London and Gibraltar) was for 'Leave'4 (see: Menon \& Fowler (2016), Goodwin \& Heath (2016)).

It is the result of the referendum in Scotland, together with the position of the Scottish Government (consistently advocating Scotland's membership in the EU) that brought us about to analyse whether Brexit will cause the whole Britain to leave the EU.

The influence of Brexit on UK's disintegration is analysed in a broader perspective of several issues concerned with the state's decision to withdraw from the EU. We present the possible perspectives of analysis of the effects of Brexit. We show, by quoting some social and economic data, that the decision to leave the EU did not have economic grounds. Then the legal framework of leaving international organisation is analysed. We analyse the legal regime of Brexit and its possible influence on UK's disintegration. Economic and legal study allows to assess the economic effects of Brexit and future regime of EU-UK relations.

\section{Methods}

The research is an interdisciplinary economic and law study. We use economic methods - quantitative and qualitative analysis of socio-economic indicators related to UK's membership in EU; legal methods applicable to the research of international institutions using institutional and functional approaches. Con-

${ }^{1}$ More information about the UK's referendum: UK Parliament (2017).

2 The issue of the internal procedure was the subject of dispute, as the government considered that it does not need a parliamentary mandate, but the view was not shared by the Supreme Court (2017).

3 In 1998 the 3 devolved legislatures were established based on: the Scotland Act 1998; the Northern Ireland Act 1998; and the Government of Wales Act 1998 (superseded in 2006). The relationship between UK's and Scottish parliaments is regulated by Sewel Convention (Scottish Government, 2017b).

${ }^{4}$ Paradoxically, in the first national referendum held in UK on 4.06.1975, England provided the strongest support for remaining in the then EEC, with a much smaller margin for membership in Scotland and Northern Ireland (Henderson et al., 2016, p. 187). 
clusions are formulated on the basis of the synthesis of the results and approximations. This interdisciplinary nature of the research is an element of novelty of the research.

\section{Results}

\subsection{Possible perspectives of analysis of the effects of Brexit}

There are several perspectives of Brexit which can be analyzed. Firstly, from the standpoint of affected entities there may be internal (domestic), European (EU), or international points of view of an analysis. Secondly, the issues that need to be regulated due to Brexit can also be examined.

We limit the internal perspective to the 'case' of United Kingdom (we do not deal with other countries' domestic perspectives, European or international ones $\left.^{5}\right)$.

The UK 'case' is understood as a process which led to the national referendum on the UK's membership of the EU. It is a process, in which its main personalised actors (i.e. politicians, not the society) did not expect the actual outcome. Both the politicians/parties calling for a vote in favour of remaining in the EU and those urging to vote against awaited benefits of a referendum resulting in a decision to stay in the EU (see more about the politics of Brexit in: Jensen \& Snaith (2016)). Just the announcement of referendum has brought the United Kingdom improved membership conditions and secured some significant concessions from EU partners (UK Parliament, 2016). The referendum was an opportunity to create new social groups, parties and new leaders. It was an attractive perspective for both 'challengers' ${ }^{\prime 6}$ and 'old' leaders expecting to confirm their position (and, in fact, strengthen it, since the new competitors are less experienced ${ }^{7}$ ).

Equally interesting is the issue of UK's legal framework of Brexit and creation of a new British legal order (i.e. preserving/changing the 'acquis'). The challenge is to place UK in a new economic and political network of relations in Europe and in the world. UK will be a new country in international economic

${ }^{5}$ From the EU point of view, both future relations with the UK and the impact of Brexit on the European integration are important. The spectrum of possibilities in the second case is wide: from deepening of integration to disintegration of the EU. Of course, the extreme scenario will not occur.

${ }^{6}$ Such as Boris Johnson (Ministry for Foreign Affairs) whose promotions for years were blocked by a petrified political system.

7 David Cameron could count on it. His position in both the (conservative) party and nationwide would have strengthened in case of the failure of Brexit. He would become the Prime Minister who not only was successful in renegotiating the terms of the EU membership (like Margaret Thatcher), but who also respects citizens by asking the public for their opinion. 
relations that has to create a new legal framework (e.g. of bilateral agreements) which will replace the current EU policies.

The scale of challenges is difficult to imagine, because the British expectations may be far greater than the possibilities ${ }^{8}$, and the 'Norwegian model'" is a nebulous one (Honley, 2016) ${ }^{10}$. Difficulties arise in political relations too, as the UK will not officially become a new state - it will, for example, continue its status in UNSC as a permanent member - but for many years British policy has been defined and implemented in the EU CFSP formula.

One of other perspectives of Brexit analysis is the subject matter of the process. Specifically, the concern may be raised whether the referendum is the right form of direct democracy. This well-known, yet marginalised, institution (regularly practiced only in Switzerland) was recalled from the past by Charles de Gaulle, for whom it was a tool of confirmation - in a popularity contest of his political mandate. The referendum questions were simple and the decisions were sui generis self-executing. In 1962, the referendum 'for or against' direct elections of the President of the V Republic was to legitimize the power after granting Algeria the independence - de Gaulle won. In 1969, by rejecting the reform of the Senate the citizens denied further legitimisation of power, which in 1968 used army to suppress students' protests (Bouissou, 1978; Cadart, 1976). Similarly, the vote against the Constitution for Europe (in 2005) was the refusal of President Chirac's political mandate ${ }^{11}$.

The referendum on Brexit (quite similar to the vote on the European Treaties) is different on the merits. The issue of EU membership, although decided in the accession referendums, does not allow an unequivocal assessment and the choice based on it. Decision makers are not in a position to assess conse-

${ }^{8}$ For example, the Australian government rejects the possibility of negotiating a bilateral trade treaty before the Brexit (see: Babin (2016)).

9 When Norwegians in a referendum in 1994 (for the second time) rejected an EU accession agreement, while Finland and Sweden made a positive decision, Norway considered it desirable to create a legal framework for the relationship with the EU, which would maintain the special nature of Nordic cooperation. Norway is a member of the EEA, with full access to single market, including free movement of people, obliged to make a financial contribution and accept majority of EU laws. As a part of Nordic cooperation Norway participates in EU 'decisions shaping'. In essence, it is a member of the EU de facto not being de jure.

10 Apart from the Norwegian model of relations with EU, other approaches include Swiss, Turkish, Canadian and Asian (state cities of Singapore and Hong Kong) ones (see more: BBC News (2016), UK Government (2016)).

${ }^{11}$ His victory in the 2002 election (82\% of the votes in the second round) in a consensus opinion - was the result of the vote against Jean-Marie Le Pen. By rejecting the Constitution (of which France was the chief author of concepts and specific solutions) his supporters in the presidential election wanted to express the evaluation of Chirac and his presidency. 
quences that are not subject to verification not only in the short but also in medium term ${ }^{12}$.

\subsection{Irrationality of British decision to leave the EU}

The referendum campaign of proponents of UK remaining in the EU was based on warnings of economic risks of leaving the EU, rather than the benefits of membership. At the same time, the political and economic situation affected by the financial and refugee crises, as well as the efforts to prevent Greece from leaving Eurozone has created a favourable ground for the populist Eurosceptic campaign (Menon \& Fowler, 2016; Bort, 2016).

Economic and social indicators (charts 1-6) prove that, contrary to believes popular in Britain, the standard of living in UK has dramatically improved since its accession both in absolute terms, and relative to other EU member states ${ }^{13}$. Some indicators also show the advantage of UK results over American ones. Since joining the EU in 1973, British GDP per capita grew by $102 \%$, exceeding the $73 \%$ growth of the US and $79 \%$ and $89 \%$ of Italy and France respectively. The UK's GDP is above the EU-15 average since mid-1990 (with exception of the last economic crisis years). Similarly, the UK has scored the highest growth of employment among the biggest EU economies. Some 'soft' indicators, such as infant mortality rate, tertiary education ratio, human development index also illustrate outstanding performance of UK when compared to EU members and the US. We concentrate on these 'soft' indicators, as they are directly linked with the economic changes and at the same they more clearly than 'hard' economic data reflect individuals' participation in those changes.

Obviously, the membership in EU has been just one of the factor that enabled positive changes, but along with the reforms undertaken by M. Thatcher and the economic policy of the UK's successive governments, the quality of life of British citizens has improved.

Due to limited space, we are unable to analyze more deeply other economic indicators, but it is worth to mention that irrationality of the decision to leave the EU is additionally strengthen by the fact that over $50 \%$ of the UK's exports is directed to other EU member countries and that the position of London as a global financial center is endangered.

12 Thus, the basic verifiable argument for democracy — the rationality of a decision that is a resultant of individual decisions - does not work. See the theories of 'public choice' and 'rational expectations' versus e.g. 'money illusion'. Another problem in the referendum on Brexit were the conscious lies. After the referendum Nigel Farage cynically admitted it (New Statesman, 2016).

13 The sample of countries vary depending on data available, but in general is limited to Germany, France and Italy, i.e. the largest EU Member States. 


\subsection{Withdrawal from international organization - legal framework and practice}

When a state (or any other entity) joins an international organization, it assesses the costs and benefits of membership, or of staying outside the organization, and it evaluates the international relations (liberal institutionalism or realism). It takes into account various and heterogeneous factors: economic, financial, social, and political (including security determinants, the role and rank in international relations). It is difficult to reconstruct the candidate's to membership decision-making process, partly because the process at first is not transparent (it is easier in case of an international organization, e.g. the EU, because the process is more transparent). Even if the balance of benefits and costs of membership is presented, it more often appears to be part of a political strategy than an accurate cost-benefit calculation, and is burdened with the uncertainty risk (as it is a long-term forecast). Undoubtedly, however, whoever is joining an organization is striving for sustainable benefits. The functioning of an organization is possible in this respect only because the assessment of membership is subjective, based on an unidentified set of factors with different weights assigned, and the fact that membership in an international organization is a positive-sum game (Hegel, 1969, pp. 188, 191-193, \$182 and \$187). The strategy of joining an international organization should be long-term.

Such a perspective is even more important with regard to the decision to leave the organisation. In this case, it is important to evaluate the change of decision by members of organization and actors of international relations from the point of view, among others, credibility in performance of obligations. Following the balance taking into account this factor, states avoid the decisions to withdraw from organizations. The reason is that any such a decision is final, and - according to Benjamin Disraeli — 'Finality is not the language of politics' (Cohen \& Cohen, 1973, p. 140) ${ }^{14}$. But if circumstances change (rebus sic stantibus), they make such decisions.

The decisions to leave either express individual dissatisfaction with the membership of the organization ${ }^{15}$ or general, negative evaluation of the organization's activities ${ }^{16}$.

The statutes of organizations often do not regulate the legal framework of the withdrawal. In such a case, the right to leave is confirmed by Art. 56 of Vienna Convention on the Law of Treaties. The UN is a special case. The UN Charter deliberately omits the withdrawal issue (in order to avoid the repetition of the situation in the League of Nations) without denying that right. However, in one case of withdrawal (Indonesia 1965), after the country changed the decision, it was considered that there was no exit but the cooperation "was

14 Speech in House of Commons on 28.02.1859.

15 As in case of Albania exiting ILO in 1965.

${ }^{16}$ As in cases of exiting UNESCO by USA in 1984 and by UK in 1985, and USA leaving ILO in 1977. 
ceased'. Similarly, statutes of the organization of the UN system are also silent on the issue. This solution neither prevents leaving nor controversies related with the whole process. The controversies may be avoided when a termination clause is included in the organization's statute. These clauses most often provide for the mode of termination of an agreement and set a date for the effectiveness of such a statement ${ }^{17}$.

In order to reduce the costs of decisions to leave an organisation, the statutes of some of them facilitate the process, e.g. in a situation of dissatisfaction with changing the statute ${ }^{18}$.

Analysis of instances of exits from organisations indicates the overriding value of the political factor of the decision. It also proves that they were elements of searching for confrontation, not compromise. However, there is no doubt that further membership in the organization may be considered by the state as an undesirable limitation of the choice of strategy or tactics. It should be remembered that the raison d'État is guided by the statement: 'We have no eternal allies, and we have no perpetual enemies. Our interests are eternal and perpetual, and those interests are our duty to follow' ${ }^{19}$.

\subsection{The legal basis of leaving the European Union}

The regulations concerning leaving the ECs were changing. The Treaty of Paris establishing the ECSC did not regulate the issue of the leaving the Organization. It was concluded for a period of fifty years (Art. 97) and after that it expired. The EEC and Euratom treaties did not mention neither the issue of leaving the Organisations nor the period of their existence (they were concluded for unlimited time, Art. 51 TEU).

It has been, rightfully, assumed that membership in the Communities and the Union creates such deep connections in all the areas of integration ('point of no return') that it is difficult imagine - due to costs - a unilateral decision of a member state to leave the Organisation.

In response to the emerging allegations of anti-European politicians that the EU cannot be left, and the quiet fears of 'wild' exits, the Treaty on European Union introduced a provision of Art. $50 \mathrm{sec} .1$ providing for the right of each Member State to withdraw from the EU in accordance with its constitutional requirements. It also regulates the mode of departure (sec. 2-4), which is quasi-inverse of the accession process. According to this regulations, the procedure commences the notification of the intention of withdrawal by a Member State to the European Council. The European Council then provides guidelines

17 As in ILO, FAO, IBRD.

${ }^{18}$ For example art. XVIII letter D of the statute of International Atomic Energy Agency.

19 This is a travesty of statement about the foreign policy of Lord Palmerston (lived between 1784-1865, served twice as British Prime Minister in 1859-1865). Speech to the House of Commons on 1.03.1848 (Hansard, 2017). 
for the EU negotiations with that State, 'setting out the arrangements for its withdrawal, taking account of the framework for its future relationship with the Union'. The agreement regulating all issues relating to withdrawal is concluded on behalf of the Union by the EU Council, after obtaining the consent of the European Parliament. The actual date of leaving the EU is from the date of entry into force of the withdrawal agreement or, if that was not possible, 2 years after the notification, or later if the European Council, in agreement with the Member State, unanimously decides to extend this period. The withdrawing Member State does not participate in the EU decision-making process. If the Member State changes its mind and asks to re-join, its application request is subject to the general procedure of Art. 49 TEU (art. 50 par. 5).

On March 29, 2017 The UK Prime Minister has started the legal procedure of United Kingdom's withdrawal by notifying the European Council in accordance with Art. 50. Conclusion of the withdrawal agreement may take a maximum of 2 years. The negotiations may cover legal framework of future relations, so the deadline will be extremely difficult to meet. Difficulties are mounted by the difference in attitudes: the EU side opts for non-combining terms of withdrawal and future trade relations, while the British want simultaneous negotiations on these two matters ${ }^{20}$. Michel Barnier ${ }^{21}$, a former French minister and European Commissioner who is the EU's chief Brexit negotiator announced the conclusion of the negotiations at maximum 18 months, reserving the remainder for the remaining procedures (Crisp \& Tampest, 2016, Barnier, 2016).

\subsection{Between Brit-in and Br-exit}

The United Kingdom was admitted to the European Communities in 1973. There were two main reasons of late admission. The first was the vacuum of political strategy of the British Government, which assumed that non-joining the ECSC would provide an electoral victory (which proved to be untrue). The UK has, however, co-operated with the ECSC on a non-member status. The second reason was the abandonment of the ally (France) during the Suez Crisis of 1956. In response, France hastily began to develop institutional European integration, creating an EEC and Euratom with a door closed to Britain. Since EFTA appeared a failure, the UK, after walking to Canossa, obtained the French approval for ECs membership. The UK later paid political price for this consent, accept-

20 'We believe it is necessary to agree the terms of our future partnership alongside those of our withdrawal from the EU' (UK Government, 2017).

${ }^{21}$ From the UK's perspective, the choice of a chief EU negotiator could not be less favorable. Barnier combines excellent education with knowledge of the EU (between 1999-2004 and 2010-2014 he served as European Commissioner, in 2009 was elected as a Member of the European Parliament) with political position and connections (Minister of Foreign Affairs 2004-2005, Minister of State for European Affairs 1995-1997, Minister of the Environment and Way of Life 1993-1995). He was a member of the 'Group Amato', which prepared the Constitution for Europe. 
ing the unequal status. Also Germans paid the price, but they acknowledged that triangulation of relations (from the 'France-Germany' to the 'FranceGermany-Great Britain') is worth the extra contribution to the budget and postponing the change of decision-making procedures ${ }^{22}$.

Franco-British relations in the Communities have never reached the level of trust and cooperation from the period between the end of the First World War and the Suez Crisis. The situation was worsened by the fact that the UK was acting in the Communities as a guest who voluntarily joins the party when the main dish is already on the table and decides to change the menu, rearrange the table and change the seating of the guests. The British occupied the main economic and world politics table as a member of the Communities too often demonstrating separateness from Europe and dissatisfaction with the membership.

The situation for both parties was uncomfortable. The continental members of the Communities were aware that exit of the UK from the EC would harm integration much more than its non-accession and the British were aware of the lack of choice. The British Government has decided to renegotiate the terms of membership.

Since 1974 the UK has contested both the expenditures on Common Agricultural Policy $(\mathrm{CAP})^{23}$ and the difference between the British contribution to the CAP budget and the CAP receipts. As a result of decisions taken at the European Council summit in Fontainebleau in 1984, the UK's financial contribution to the EU budget has been reduced. Other members agreed to bear the financial consequences of UK's rebate on VAT payments (Grumbling about le cheque britannique in France rivals UK antagonism to the CAP - Begg, 2016, p. 44). This rebate was the subject of constant disputes. Opponents raised the issue of reduction of EU spending on the CAP and the improvement of the UK's economic situation. Supporters pointed to a persistent difference between expenditures and receipts from the EU budget ${ }^{24}$.

\subsection{Brexit as a factor of disintegration of UK}

Apart from the whole spectrum of issues involved with UK's exit from the EU there is a question of relations of Scotland with the EU if Scotland becomes an independent 'state'. On March 28, 2017 the Scottish Parliament mandated the Scottish Government to open formal talks with the UK Government to enable a second independence referendum to be held, at around the time Britain

22 Change from unanimity to majority voting.

${ }^{23}$ The expenditures on CAP were reaching up to 70\% of EU budget till the reform in 2000 , since then they have decreased to $40 \%$ and are set to continue falling to $33 \%$ in 2020. In 2016 they amounted 38\% (55 billion euros) (see: European Commission (2016)).

24 The difference is estimated at around 10 billion euros annually between 2007 and 2013. 
leaves the EU, in spring 201925. Scottish First Minister, Nicola Sturgeon said on this occasion: 'We know that Brexit threatens a hugely damaging and uncertain future for Scotland, and it would not be right if the people of Scotland having been told in 2014 that the only way to protect our place in Europe was to vote against independence - were denied a choice' (Scottish Government, 2017a).

There is no doubt that Scotland can - if it so wishes - become a member of the EU. Obviously it fulfils all accession criteria (or Copenhagen criteria) ${ }^{26}$.

The accession negotiations can be quick and easy, which does not mean hassle-free. The official, but informal (in the sense that there is no treaty-legal basis) EU position announcing the need for a 'normal' (i.e. Article 49 TEU) accession procedure when Scotland becomes independent state must be analyzed in a multi-faceted way, since its content consists of many elements and has many different recipients. One of the direct technical problems is the relationship of potential Scotland's statehood with the British statehood in association with Scotland's EU membership.

The previous cases of 'exits' from the $\mathrm{EU}^{27}$ do not allow for making predictions about Scotland's case. The only matter common for all these cases is that states that want to leave the EU in such a way that they still want to 'stay in there', because the basis for their decisions are ad hoc political calculations rather than substantive arguments (e.g. considering economic interest). This is undoubtedly due to the fact that the alternative to participation is 'out of EU area, out of business/market'. What differs the current exit from the previous cases is that (new)UK will be recognized as the continuator of (old)UK, while Scotland will be a new state - a recognized international body. However, it is the UK departing from the EU, and the new state by nature cannot be neither a continuator nor a successor of membership.

The message about Scotland's independence is a separate issue. The EU and the US do not support any separatism seeing them as a threat to stability. They are even more reserved in this case due to the threat to the stability of one of the pillars of the Atlantic alliance and the 'security community'. Undoubtedly, the promise of automatic membership in the EU would support the backers of Scotland's independence, as the vote 'for' in the independence referendum would be a vote for maintaining the status quo (stay in the EU) and not for the travel to the unknown (to independence).

25 Also in Northern Ireland attempts are made to leave UK. Sinn Fein is calling for a referendum on whether to join the Irish republic.

26 Scotland would be a 'European' state with constitution guaranteeing democracy, the rule of law, human rights and respect for and protection of minorities (Article 2 TEU). Its market economy will be able to function within the EU market. Scotland will be able to adopt the 'acquis' (in fact it will not abolish the 'acquis') (European Commission, 2017).

27 The EU does not have a full-fledged experience of leaving the Organization. There are some similar cases, namely Greenland, Guadeloupe (or more precisely Saint-Martin and Saint-Barthelemy) and with respect to all the differences - Norway. 
But the circle of recipients of this message is not limited to UK and Scotland. The first, but not direct, address is Catalonia, which the EU, in cooperation with Spain, wants to warn against the independence that will lead to the need for applying for EU membership, which Spain can block (as the unanimity is required).

\section{Conclusion}

The results of UK referendum on membership of the EU are hard to imagine and predict. We identify three main areas that need special attention.

First, in the long run, Brexit will weaken the UK integrity, even if Scotland does not become independent. In case of breakup of Great Britain, the consequences will be more far-reaching and difficult to predict. At the same time, we consider the scenario of Scotland's accession to the EU after gaining independence as highly probable. It is supported by the coherence of the Scottish supporters of independence with economic interests of the state.

Second, the UK's decision to leave the EU affects the perception on European integration. Even though Brexit is in line with the letter of European's treaties, it is contrary to their spirit. The European integration is no longer perceived as 'a road of no return'. Its attractiveness is also lowered. The UK rejects the paradigm that the 'security community' is a source of prosperity and security. Weakening of UK ties with the EU will have a significant impact on the strength of European identity and its external perception.

Third, irrespective of the EU-UK regime, Brexit will affect transatlantic order and western hemisphere. It reduces the integrity of western hemisphere. Brexit will also weaken the Atlantic alliance.

\section{References}

Babin, J. (2016). Brexit: l'Australie refroidit le Royaume-Uni. Les Echos, 25.10.2016. Retrieved 10.03.2017 from https: / /www.lesechos.fr.

Barnier, M. (2016). Introductory comments by Michel Barnier. Press briefing, 06.12.2016. Retrieved 10.03.2017 from https://ec.europa.eu.

BBC News. (2016). Five models for post-Brexit UK trade. Retrieved 05.03.2017 from http://www.bbc.com.

Begg, I. (2016). The EU Budget and UK Contribution. National Institute Economic Review, 236(1). doi:10.1177/002795011623600106.

Bort, E. (2016). Brexit: Europe's 'Black Thursday' and Scotland's Future. Scottish Affairs, 25(4). doi:10.3366/scot.2016.0155.

Bouissou, M. (1978). La pratique référendaire en France. Revue internationale de droit compare, 28(2). doi:10.3406/ridc.1976.16657. 
Cadart, J. (1976). Les inconvénients et les dangers plébiscitaires du référendum d'initiative présidentielle et gouvernementale en France depuis 1958 et les remèdes désirables. Revue internationale de droit compare, 28(2). doi:10.3406/ ridc.1976.16658.

Cohen, J.M., \& Cohen, M.J. (1973). The Penguin Dictionary of Quotations. Middlesex: Penguin Books Ltd.

Crisp, J., \& Tampest, M. (2016). EU Brexit boss sets October 2018 deadline for UK divorce talks. Retrieved 10.03.2017 from http://www.euractiv.com.

European Commission. (2016). EU annual budget life-cycle: figures. Retrieved 15.03.2017 from: http://ec.europa.eu.

European Commission. (2017). Accession criteria. Retrieved 15.03.2017 from https://ec.europa.eu.

Goodwin, M.J., \& Heath, O. (2016). The 2016 Referendum, Brexit and the Left Behind: An Aggregate-level Analysis of the Result. The Political Quarterly, 87(3). doi:10.1111/1467-923X.12285.

Hansard. (2017). Hansard's Parliamentary Debates, 3rd series, Vol. 97, col. 122. Retrieved 11.01.2018 from http://hansard.millbanksystems.com.

Hegel, G.W.F. (1969). Zasady filozofii prawa. Warszawa: PWN.

Henderson, A., Jeffery, C., Lineira, R., Scully, R., Wincott, D., \& Wyn Jones, R. (2016). England, Englishness and Brexit. Political Quarterly, 87(2). doi:10.1111/1467-923X.12262.

Honley, J. (2016). Can the UK adopt the 'Norway model' as its Brexit solution? The Guardian, 01.12.2016.

Jensen, M.D., \& Snaith, H. (2016). When politics prevails: the political economy of a Brexit. Journal of European Public Policy, 23(9). doi:10.1080/135017 63.2016.1174531.

Menon, A., \& Fowler B. (2016). Hard or soft? The politics of Brexit. National Institute Economic Review, 238(1). doi:10.1177/002795011623800110.

New Statesman. (2016). Watch: The evidence Nigel Farage said money sent to the EU should go to the NHS. Retrieved 1.03.2017 from http:/ / www.newstatesman. com.

OECD.stat (2017). Retrieved 15.12.2017 from http://stats.oecd.org.

Scottish Government. (2017a). Parliament backs independence referendum. Retrieved 29.03.2017 from https://news.gov.scot.

Scottish Government. (2017b). Sewel Convention - Legislative Consent Motions. Retrieved 10.02.2017 from http://www.gov.scot.

Supreme Court. (2017). $R$ (on the application of Miller and Dos Santos) v Secretary of State for Exiting the European Union and associated references case. Retrieved 10.02.2017 from https://www.supremecourt.uk.

The Conference Board Total Economy Database. (2017). Retrieved 11.01.2018 from https: / /www.conference-board.org.

Uberoi, E. (2016). European Union Referendum 2016. Commons Briefing Papers, CBP-7639. 
UK Government. (2016). Alternatives to membership: possible models for the United Kingdom outside the European Union. Retrieved 10.03.2017 from https:// www.gov.uk.

UK Government. (2017). Prime Minister's letter to the European Council. Retrieved 30.03.2017 from https: / /www.gov.uk.

UK Parliament. (2016). EU referendum: UK's EU reform negotiations and the Tusk package. Retrieved 12.02.2017 from http://researchbriefings.parliament. uk.

UK Parliament. (2017). Background to the UK's EU referendum 2016. Retrieved 10.02.2017 from http://www.parliament.uk.

UNDP. (2016). Human Development Report. Retrieved 11.01.2018 from http:// hdr.undp.org.

World Bank. (2017). World Development Indicators. Retrieved 11.01.2018 from http://databank.worldbank.org.

\section{Acknowledgements}

Author contributions: authors have given an approval to the final version of the article. Authors contributed to this work equally.

Funding: this research was undertaken as part of the statutory research in the Collegium of World Economy, Warsaw School of Economics project and was fully funded by the Warsaw School of Economics.

Note: the results of this study were presented at 9th International Conference on Applied Economics Contemporary issues in Economy (June 22-23, Torun, Poland).

\section{Appendix}

Table 1.

Proportion of the votes on referendum of UK's membership in EU (in\%)

\begin{tabular}{|c|c|c|}
\hline Items & Leave & Remain \\
\hline England & 53.4 & 46.6 \\
\hline Wales & 52.5 & 47.5 \\
\hline Scotland & 38.0 & 62.0 \\
\hline Northern Ireland & 44.2 & 55.8 \\
\hline National result & 51.9 & 48.1 \\
\hline
\end{tabular}

Source: Uberoi (2016). 


\section{Chart 1.}

British GDP per person as a \% of EU-15 average in years 1973-2016 (EU-15=100) 130

120

110

100

90

80

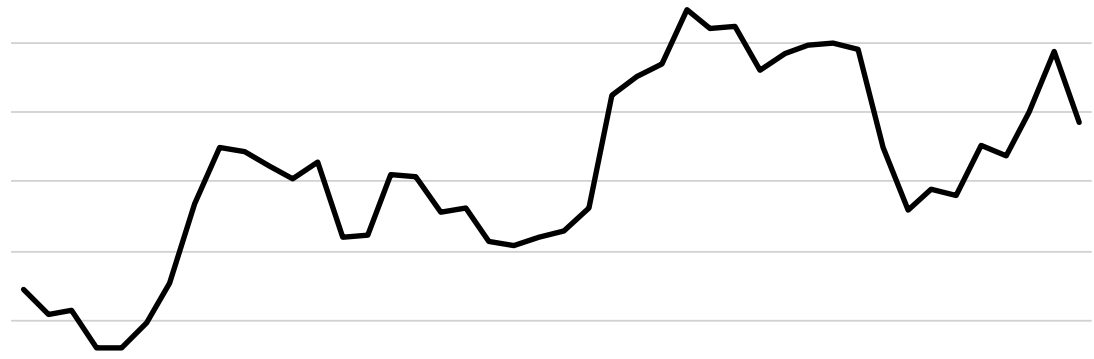

70

60

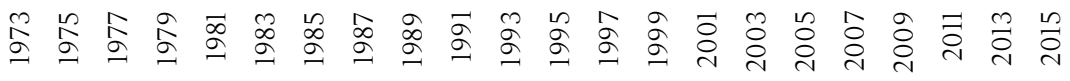

Source: Own preparation based on OECD.stat (2017).

Chart 2.

Growth of GDP per capita in years 1973-2017 (in \%) (1973 as a base year)

110

100

90

80

70

60

50

40

30

20

10

0

$-10$

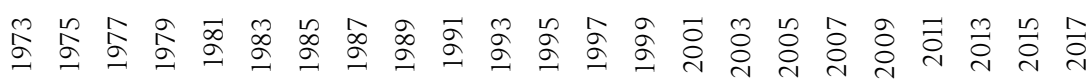

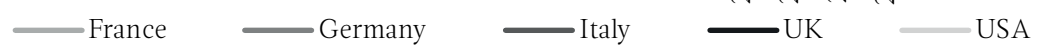

Source: Own preparation based on The Conference Board Total Economy Database (2017). 


\section{Chart 3.}

Infant mortality rate in years 1973-2016 (per 1,000 live births)

30

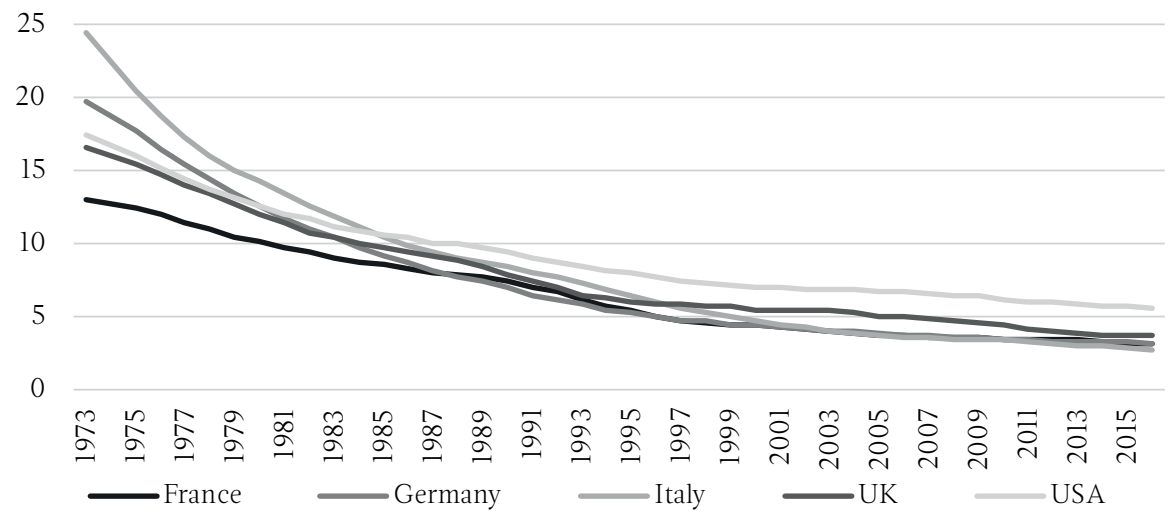

Source: Own preparation based on World Bank (2017).

\section{Chart 4.}

Tertiary education — gross enrolment ratio in years 1973-2014 (in \%)

70

60

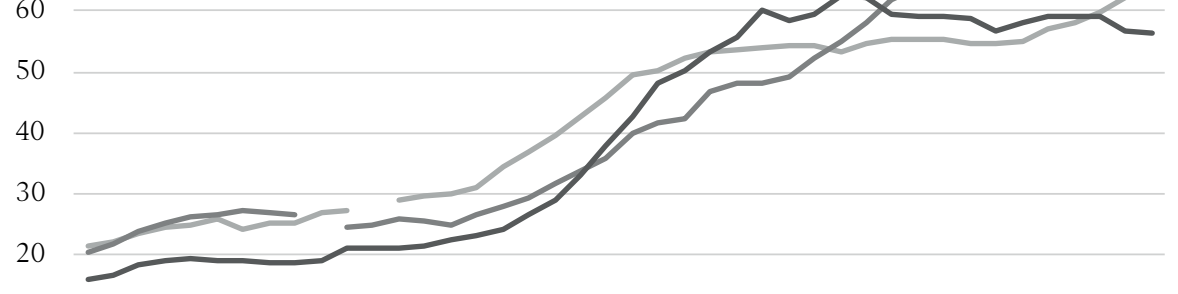

10

0

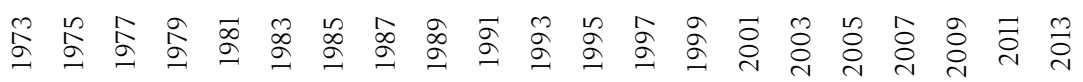

$$
\begin{aligned}
& \text { - France Italy —UK }
\end{aligned}
$$

Source: Own preparation based on World Bank (2017). 


\section{Chart 5.}

Growth of employment in years 1973-2017 (in \%) (1973 as a base year)

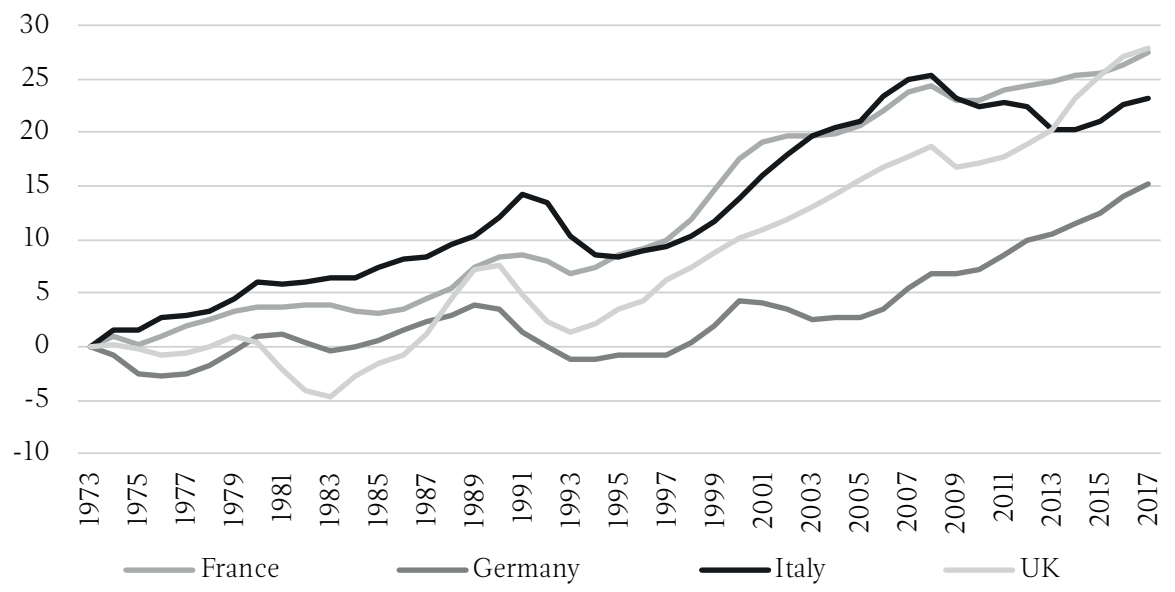

Source: Own preparation based on The Conference Board Total Economy Database (2017).

\section{Chart 6.}

Human Development Index in years 1990-2015

0.95

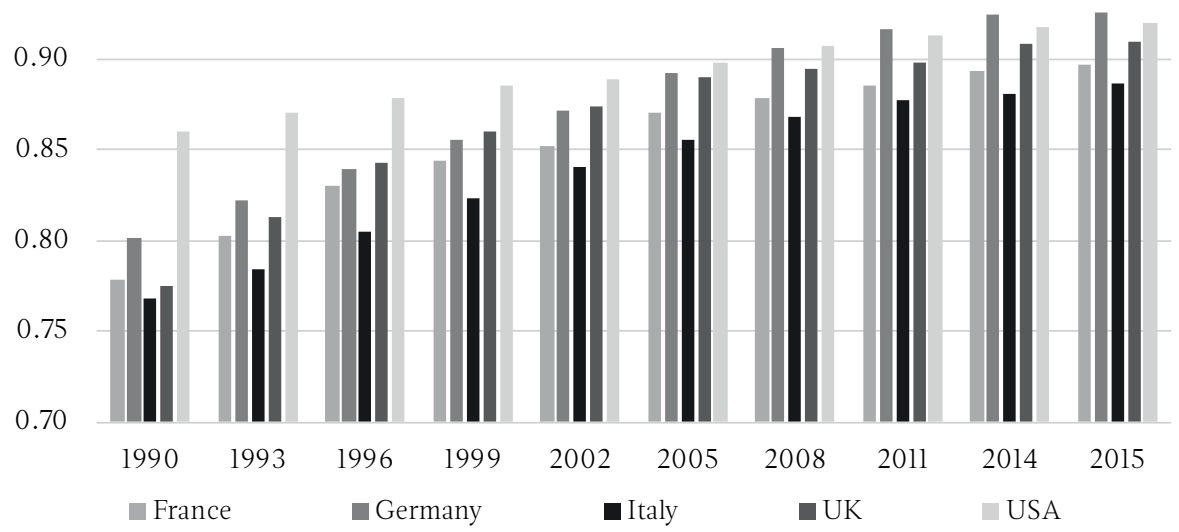

Source: Own preparation based on UNDP (2016). 